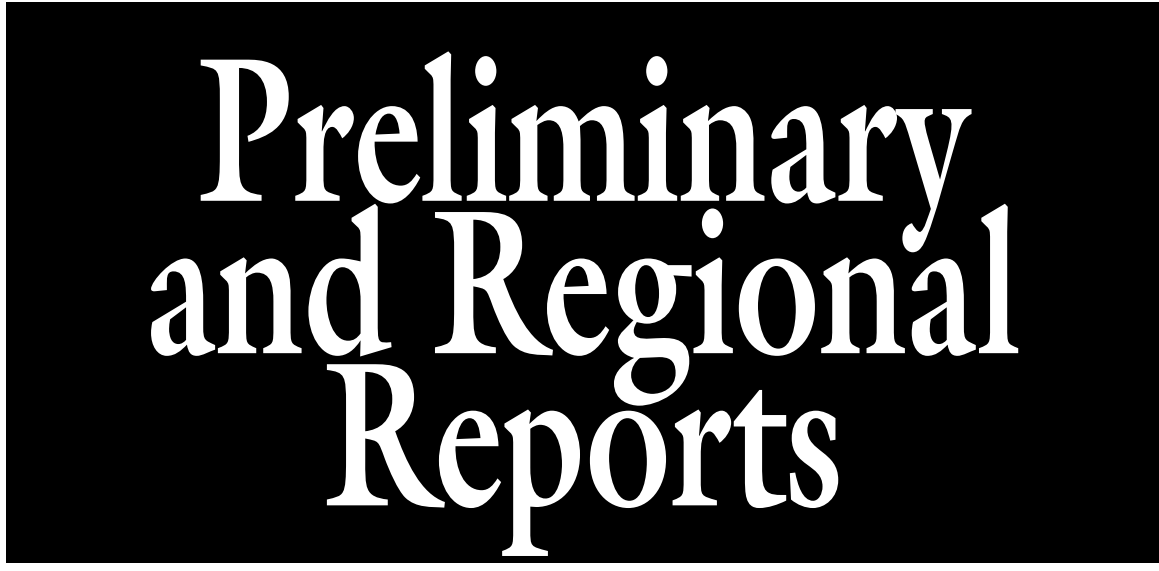

\title{
Composting as an Alternative Management Strategy for Sargassum Drifts on Coastlines
}

\author{
Jen A. Sembera ${ }^{1}$, Erica J. Meier ${ }^{1}$, and Tina M. Waliczek ${ }^{2,3}$
}

ADDITIONAL INDEX WORDs. aquatic plant management, beach management, compost, compost quality, exotic, invasive species, Sargassum fluitans, Sargassum natans, brown algae, seaweed

SUMMARY. Massive drifts of sargassum (Sargassum fluitans and Sargassum natans) float onto the United States Gulf, Atlantic, and European shorelines regularly throughout the spring and summer months. To maintain tourist appeal and subsequently, the tourism industry, the standard practice of Texas beach communities has been to mechanically remove the sargassum seaweed and integrate it into dunes along the shoreline or dispose of the material in the landfill. The purpose of this study was to evaluate the potential to manage the invasive species sargassum using composting and to test the quality of the resulting compost. This study used $\approx 12$ yard $^{3}$ of sargassum as a feedstock mixed with cafeteria food waste and local wood chips, using a total of $\approx 72$ yard $^{3}$ of feedstocks, to create nearly 25 yard $^{3}$ of stabilized compost. The final compost products were of equal or higher quality to current compost standards. Therefore, this study determined that the composting and waste management industries can use sargassum as a feedstock to create a desirable compost product that could be used in the horticulture and agriculture industries, while helping to manage this invasive species.

$\mathrm{N}$ early 10,000 different types of seaweed algae thrive in the world's oceans and seas (Abbott and Dawson, 1978; Fritsch, 1965). Algae in the genus Sargassum of the sargassum family (Sargassaceae) include more than 150 species distributed throughout the tropical and temperate oceans around the world, thriving in warmer oceans and seas (Abbott and Dawson, 1978; Fritsch, 1965). Two planktonic species (S. fluitans and $S$. natans) drift en masse onto the shores of the Texas Gulf Coast, and

Department of Agriculture, Texas State University, 601 University Drive, San Marcos, TX 78666

${ }^{1}$ Graduate Student.

${ }^{2}$ Professor of Horticulture

${ }^{3}$ Corresponding author. E-mail: tcl0@txstate.edu.

https://doi.org/10.21273/HORTTECH03836-17 are known collectively as brown algae, gulfweed, seaweed, sea holly, or sargassum. Sargassum that "washes" to shore can accumulate into massive, troublesome mounds, which substantially affects local coastal economies that rely on the beaches associated with the local tourism industry (Gaskill, 2015; Texas General Land Office, 2007). Sargassum was added to the Global Invasive Species Database in 2011 (Invasive Species Specialist Group, 2011) and has been identified along the shorelines of North America, Central America, the Caribbean Islands, the western Atlantic, Southwest Asia, and Southeast Asia (Guiry and Guiry, 2013).

Free-floating species of sargassum reproduce asexually by fragmentation (Awasthi, 2005; Rogers, 2011). Both require warmer oceans and sea temperatures to thrive, as well as chemical properties in their aquatic environment to survive (Abbott and Dawson, 1978; Fritsch, 1965; Round, 1981). Sargassum decreases in size after landing on the shore, and within a 5 -d period, the seaweed decreases about three times in volume, becomes brittle, and changes from a light yellow to dark brown color (Round, 1981).

Nutrients absorbed from the sea, in combination with the energy from the sun, make seaweed rich in major nutrients and trace nutrients, and these nutrients can be used as soil amendments and fertilizers (Verkleij, 1992). Williams and Feagin (2010) studied the application of sargassum on native coastal plants beach sunflower (Helianthus debilis), fiddle-leaf morning glory (Ipomoea stolonifora), bitter panicgrass (Panicum amarum), seashore dropseed (Sporobolus virginicus), and seaside oats (Uniola paniculata) as a natural solution to enhance native dune plant growth. The study found sargassum acted as a natural fertilizer for bitter panicgrass (Williams and Feagin, 2010). Another study (Verkleij, 1992) found adding a seaweed-based soil amendment supplemented nutrient-poor sandy soils (Verkleij, 1992). In addition, some biological agriculture and horticulture practices have applied diluted seaweed extracts to enhance growth, deter insects and diseases, and improve quality of harvests (Verkleij, 1992).

\begin{tabular}{llll}
\hline $\begin{array}{l}\text { Units } \\
\begin{array}{l}\text { To convert U.S. to SI, } \\
\text { multiply by }\end{array}\end{array}$ & U.S. unit & SI unit & $\begin{array}{l}\text { To convert SI to U.S., } \\
\text { multiply by }\end{array}$ \\
\hline 0.4047 & $\mathrm{acre}(\mathrm{s})$ & $\mathrm{ha}$ & 2.4711 \\
0.3048 & $\mathrm{ft}$ & $\mathrm{m}$ & 3.2808 \\
3.7854 & $\mathrm{gal}$ & $\mathrm{L}$ & 0.2642 \\
1 & $\mathrm{mmho} / \mathrm{cm}$ & $\mathrm{dS} \cdot \mathrm{m}^{-1}$ & 1 \\
0.001 & $\mathrm{ppm}$ & $\mathrm{mg} \cdot \mathrm{g}^{-1}$ & 1,000 \\
1 & $\mathrm{ppm}$ & $\mathrm{mg} \cdot \mathrm{kg}^{-1}$ & 1 \\
0.7646 & $\mathrm{yard}$ & $\mathrm{m}^{3}$ & 1.3080 \\
$\left({ }^{\circ} \mathrm{F}-32\right) \div 1.8$ & ${ }^{\circ} \mathrm{F}$ & ${ }^{\circ} \mathrm{C}$ & $\left({ }^{\circ} \mathrm{C} \times 1.8\right)+32$ \\
& & &
\end{tabular}


Beaches along the Texas coastline are maintained by various organizations including federal and state agencies, cities, counties, and private owners (Gaskill, 2015; Texas General Land Office, 2007; Williams and Feagin, 2007). Variations of management procedures and methods are used by these organizations; however, basic beach maintenance objectives include maintaining safe and sanitary conditions, allowing for the use of recreational activities (e.g., sunbathing, camping, wildlife observation, and beach combing), monitoring trash removal, protecting wildlife habitats, and limiting the amount of sargassum on the coastline (Williams and Feagin, 2007).

The sargassum on beaches is handled using a variety of methods; if small amounts of biomass float onto the shore, large rakers are used to remove it. For large amounts, front-end loaders are allowed access to the shoreline to scrape tons of sargassum and sand, where it is then either placed at the edge of the foredune and allowed to revegetate or placed in temporary holding centers (Williams and Feagin, 2010). This method is used to create "maintenance dunes" seaward of the natural dunes (Gaskill, 2015).

Raking is only implemented during the 4-6 months of the year when the mats of sargassum rest on the shore. A large concern of some property owners and cities is that the peak times of sargassum deposits overlap with peak tourist seasons. Tourists often expect pristine beaches free from any debris and view seaweed mats as poor beach maintenance (Gaskill, 2015). In local economies that are highly dependent on tourism dollars, maintaining or increasing tourist numbers is essential (Gaskill, 2015; Texas General Land Office, 2007).

Although sargassum are used to create stabilized maintenance dunes, many coastal areas are running out of beach space because of rising sea levels, erosion, and the increasing size of these dunes (Williams et al., 2015). Even though wider dunes allow more protection from strong storms and increased native vegetation, the public demands and expects fast and easy access to the beach, and view these wider dunes or "long walks" as impeding beach enjoyment (Williams et al., 2015).

Composting is a biomechanical process during which microorganisms such as bacteria and fungi convert organic matter $(\mathrm{OM})$ and "waste" materials into a soil-like product called compost (Rynk, 1992). The addition of compost to soil provides various benefits including increasing soil fertility, improving soil structure, increasing water holding capacity, and decreasing runoff(Dougherty, 1999; Rynk, 1992). Composting is increasingly used as a waste management method, a technique for pollution diversion, and to produce a valuable commodity for agricultural, horticultural, and related users (Walker et al., 2006).

Compost created from saline feedstocks (e.g., oceanic algae) must be carefully controlled and monitored for proper electrical conductivity (EC) amounts (Vendrame and Klock-Moore, 2013). Previous studies have used irrigation to wash away the soluble salt content before or during the compost process. Eyras et al. (1998) showed that time also plays a role: compost containing high-salinity feedstock aged for 20 months contained dramatically lower amounts of salt than compost aged for 9 months. Feedstocks of high salinity also can be combined with low salinity feedstocks to dilute the final product. Finally, actively turning the piles (rather than leaving them static) was shown to increase the rate of compost creation while decreasing the level of salinity (Eyras et al., 1998).

Seaweed extracts that contained different plant phytohormones and growth regulators increased crop yields when they were applied exogenously (Panda and Nayak, 2012). Some biological agriculture and horticulture practices have used diluted seaweed extracts or "seaweed fertilizers" to "promote growth, prevent pests and disease, and improve the quality of the products" (Verkleij, 1992). Therefore, producing compost that uses seaweed as a feedstock has the potential to create a nutrient-rich soil amendment product (Klock-Moore, 2000; Panda and Nayak, 2012).

The purpose of this study was to evaluate the potential to manage the invasive species sargassum using composting and to test the quality of the resulting compost.

\section{Materials and methods}

Material collection. Removal of sargassum biomass from the shoreline and placement into vehicles for transportation was supervised by the City of Corpus Christi, TX, according to the permit established by the U.S. Army Corps of Engineers and the City of Corpus Christi Beach Adaptive Management Plan (City of Corpus Christi, 2011). Over the span of $2 \mathrm{~d}$, a total of $\approx 18$ yard $^{3}$ of "fresh" sargassum (seaweed that arrived on the shoreline during the previous $24 \mathrm{~h}$ ) was collected by employees of the City of Corpus Christi to ensure proper procedures were followed. Similar biomass amounts were harvested in related projects studying composting as a management system for invasive species (Meier et al., 2014; Montoya et al., 2013). Within $5 \mathrm{~d}$, the sargassum biomass had shrunk to 2 yard $^{3}$.

Compost PILE RECIPES AND TREATMENTS. Half of the sargassum harvest was manually washed with tap water and screened through a charcoal fiberglass screen wire to remove as much tar, salt, and sand as possible. The other half of the sargassum was left alone. Tap water used in washing the sargassum contained typical elements such as chlorine and fluoride that could affect the results in comparisons and was a limitation in the study.

A total of six piles $6 \mathrm{ft}$ in height and $10 \mathrm{ft}$ in diameter were created. Washed and unwashed sargassum piles each received $\approx 6 \operatorname{yard}^{3}(48 \%)$ of food waste generated from the kitchen cafeterias at Texas State University (San Marcos), $6 \operatorname{yard}^{3}$ (48\%) of wood chips produced and donated by a local treecare company, and $1 / 2 \operatorname{yard}^{3}(4 \%)$ of sargassum, respectively, and were replicated three times. No true control pile of compost was necessary as in compost quality tests, compost samples are compared with overall compost quality standards for the industry (U.S. Composting Council, 2002).

COMPOST PILE CREATION AND management. Compost piles were created on a 5-acre plot of land. About 2.5 acres were allocated for the compost site and the other 2.5 acres surrounding the compost site served as runoff space and a catchment pond that could withstand a 25-year, 24-h flooding event (Meier et al., 2014).

Every 5-7 d, piles were turned regularly and monitored given compost industry standards (Dougherty, 1999). Readings were taken from five areas within each pile and averaged to ensure the following ideals were reached: $\mathrm{pH}$ between 5.5 and 9.0 (Soil pH direct reading sensor; Kelway, Wyckoff, NJ), moisture content between $40 \%$ 
and $65 \%$, and temperatures greater than $62{ }^{\circ} \mathrm{C}$ for a minimum of $3 \mathrm{~d}$ (Super Duty-Fast Response Windrow Compost Thermometer; Reotemp Instrument Corp., San Diego, CA). A minimum temperature of $62{ }^{\circ} \mathrm{C}$ was chosen as the ideal temperature to achieve during the composting process to kill pathogens (Meier et al., 2014; Montoya et al., 2013). After the active composting phase, piles were allowed to cure for at least 4 weeks to complete the composting process (Dougherty, 1999; Rynk, 1992).

Compost Quality tests. After curing, samples were drawn from the compost. Sampling techniques adhered to the collection procedures specified by the Agricultural Analytical Services Laboratory at Pennsylvania
State University (2002). For each test, subsamples from each compost pile were collected from three different depths at five locations. These 15 subsamples were combined to create four 0.5-gal composite samples representative of each pile which were then sent to the Agricultural Analytical Services Laboratory's U.S. Composting Council's Seal of Testing Approval Program at Pennsylvania State University (University Park). The samples were evaluated on the following characteristics: $\mathrm{pH}$, soluble salt content or EC, moisture content, OM content, total nitrogen, total carbon, carbon:nitrogen ratio, phosphorus, potassium, calcium, magnesium, particle size, and metals arsenic, cadmium, copper, lead, mercury, molybydenum, nickel, selenium, and zinc. Respirometry and bioassay tests were also conducted to observe maturity and stability measurements of compost samples (Meier et al., 2014; Montoya et al., 2013; Pennsylvania State University, 2002; U.S. Composting Council, 2002).

Data analysis. Frequencies and descriptive data were reported at each stage of the project. An independent $t$ test was conducted using SPSS $^{\circledR}$ (version 20.0; IBM Corp., Armonk, NY) to statistically compare results from the washed and unwashed sargassum.

\section{Results and discussion}

In total, 25 yard $^{3}$ of stabilized compost was created. This bulk product, created from waste materials, was valued at $\$ 900$ on the local market

Table 1. Independent $t$ test comparisons of results of moisture included and dry weight compost quality of washed and unwashed sargassum in the study of composting as an alternative management strategy for sargassum drifts on coastlines.

\begin{tabular}{|c|c|c|c|c|c|c|c|c|}
\hline $\begin{array}{l}\text { Variable } \\
\text { (units) }^{\mathrm{z}} \\
\end{array}$ & $\begin{array}{c}\text { Washed } \\
\text { sargassum } \\
{\text { (as is basis) })^{\mathrm{y}}}\end{array}$ & $\begin{array}{c}\text { Washed } \\
\text { sargassum } \\
{\text { (dry wt basis })^{\mathrm{y}}}\end{array}$ & $\begin{array}{l}\text { Unwashed } \\
\text { sargassum } \\
\text { (as is basis) }\end{array}$ & $\begin{array}{l}\text { Unwashed } \\
\text { sargassum } \\
\text { (dry wt basis) } \\
\end{array}$ & Normal range $(\text { USCC })^{\mathrm{x}}$ & $t$ & df & $P$ \\
\hline $\mathrm{pH}$ & 8.4 & - & 8.1 & 一 & $5.0-8.5$ & 55.000 & 1 & 0.012 * \\
\hline $\begin{array}{l}\text { Soluble salts } \\
\qquad(\mathrm{mmho} / \mathrm{cm})\end{array}$ & 1.14 & - & 1.59 & - & $1-10$ & 6.067 & 1 & 0.104 \\
\hline Solids (\%) & 57.8 & - & 74.7 & - & $50-60$ & 7.840 & 1 & 0.081 \\
\hline Total nitrogen (\%) & 0.8 & 1.4 & 1.0 & 1.3 & $0.5-2.5$ (dry weight) & 9.000 & 1 & 0.700 \\
\hline Carbon $(\%)$ & 10.8 & 18.7 & 13.4 & 18 & $<54$ (dry weight) & 9.308 & 1 & 0.068 \\
\hline Carbon:nitrogen (ratio) & 13.5 & 13.5 & 13.4 & 13.4 & $<20$ (dry weight) & 269.00 & 1 & 0.002 * \\
\hline Phosphorus (\%) & 0.36 & 0.61 & 0.36 & 0.48 & - & - & 0 & - \\
\hline Potassium (\%) & 0.41 & 0.71 & 0.45 & 0.60 & - & 21.500 & 1 & $0.030^{*}$ \\
\hline Calcium (\%) & 3.5 & 6.06 & 4.83 & 6.46 & - & 6.263 & 1 & 0.101 \\
\hline Copper $\left(\mathrm{mg} \cdot \mathrm{kg}^{-1}\right)$ & 10.7 & 18.6 & 10.3 & 13.7 & $<4,300$ & 52.500 & 1 & 0.012 * \\
\hline Lead $\left(\mathrm{mg} \cdot \mathrm{kg}^{-1}\right)$ & 3.8 & 6.5 & 4.9 & 6.5 & $<420$ & 7.909 & 1 & 0.080 \\
\hline Mercury $\left(\mathrm{mg} \cdot \mathrm{kg}^{-1}\right)$ & 0.009 & 0.016 & 0.012 & 0.015 & $<840$ & 7.000 & 1 & 0.090 \\
\hline Molybednum $\left(\mathrm{mg} \cdot \mathrm{kg}^{-1}\right)$ & $<0.8$ & $<1.5$ & $<1.0$ & $<1.4$ & $<57$ & 9.000 & 1 & 0.070 \\
\hline Nickel $\left(\mathrm{mg} \cdot \mathrm{kg}^{-1}\right)$ & 5.4 & 9.3 & 4.9 & 6.5 & $<75$ & 20.600 & 1 & $0.031^{*}$ \\
\hline Selenium $\left(\mathrm{mg} \cdot \mathrm{kg}^{-1}\right)$ & $<0.8$ & $<1.5$ & $<1.0$ & $<1.4$ & $<100$ & 9.000 & 1 & 0.070 \\
\hline $\operatorname{Zinc}\left(\mathrm{mg} \cdot \mathrm{kg}^{-1}\right)$ & 35.2 & 60.9 & 38.5 & 51.5 & $<7,500$ & 22.333 & 1 & 0.028 * \\
\hline $\begin{array}{l}\text { Respirometry } \\
\text { [carbon dioxide-carbon } \\
\left.\left(\mathrm{mg} \cdot \mathrm{g}^{-1} \text { solids per day }\right)\right]\end{array}$ & 0.8 & 一 & 0.6 & - & $\begin{array}{l}<2(\text { very stable }) \\
2-8(\text { stable })\end{array}$ & 7.000 & 1 & 0.900 \\
\hline $\begin{array}{l}\text { Respirometry } \\
{[\text { carbon dioxide }} \\
\left(\mathrm{mg} \cdot \mathrm{g}^{-1} \text { organic }\right. \\
\text { matter per day })]\end{array}$ & 2.3 & - & 2.1 & - & $\begin{array}{l}<2(\text { very stable }) \\
2-8(\text { stable })\end{array}$ & 22.000 & 1 & 0.029 * \\
\hline
\end{tabular}

${ }^{\mathrm{z}} 1 \mathrm{mmho} / \mathrm{cm}=1 \mathrm{dS} \cdot \mathrm{m}^{-1}, 1 \mathrm{mg} \cdot \mathrm{kg}^{-1}=1 \mathrm{ppm}, 1 \mathrm{mg} \cdot \mathrm{g}^{-1}=1,000 \mathrm{ppm}$.

${ }^{\text {y }}$ argassum was manually washed with tap water and screened through a charcoal fiberglass screen wire to remove as much tar, salt, and sand as possible before composting. ${ }^{\mathrm{x}}$ U.S. Composting Council (USCC) 2002. 
[Garden-Ville (Creedmoor, TX), personal communication).

Compost QuAlity TESTS RESULTS. The $\mathrm{pH}$, soluble salt content, total nitrogen, total carbon, carbon: nitrogen ratio, particle size, bioassay, and respirometry measurements of all samples regardless of washing were within the ideal and desirable ranges for compost typically sold in the horticultural industry (Table 1 ). In addition, heavy-metal content did not exceed normal ranges. The compost samples were free of weed seeds, viable plant propagules of any species and pathogens (Table 1).

According to the U.S. Composting Council (2002), the ideal $\mathrm{pH}$ range for compost is between 5.0 and 8.5. The measurements of the samples ranged from 8.1 to 8.4. Although these measurements are alkaline, they were within the acceptable $\mathrm{pH}$ ranges for finished compost standards (U.S. Composting Council, 2002). Although food waste and wood chips are acidic feedstocks within compost, seaweed is slightly alkaline (Cooperband, 2002; Darlington, 2007; Dougherty, 1999; Eyras et al., 1998; Maze et al., 1993). Compost research has indicated that piles allowed to cure for 3-4 months tend to have lower $\mathrm{pH}$ measurements (Dougherty, 2002). Therefore, curing piles for longer than 1 month could allow the compost more time to become more acidic if deemed necessary.

Soluble salt content measured in each of the piles ranged from 1.10 to $1.59 \mathrm{mmho} / \mathrm{cm}$ and was within the safe range of 1.0-10.0 $\mathrm{mmho} / \mathrm{cm}$ (U.S. Composting Council, 2002). Regardless of washing the sargassum, salt content was unaffected in the final product; therefore, prewashing seaweed did not appear to be necessary in creating a quality compost.

The normal range of total nitrogen content identified by the U.S. Composting Council (2002) is between $0.5 \%$ and $2.5 \%$ (dry weight basis). The total nitrogen content in the representative samples ranged from $0.8 \%$ to $1.0 \%$. The ideal total carbon identified by the U.S. Composting Council (2002) is less than $54 \%$. The range of total carbon in the samples varied from $10.8 \%$ to $13.4 \%$. Carbon:nitrogen ratios of 20 or less allow organic nitrogen to break down to an inorganic, plant-available form of nitrogen (U.S. Composting Council, 2002). The carbon:nitrogen ratios of the samples were between 13.40 and 13.50. Therefore, the compost produced in this study should increase plant-nutrient availability when applied to soil.

Bioassay tests measured maturity of the compost based on emergence and seedling vigor. Compost was rated as "very mature" if emergence readings are greater than $90 \%$ and seedling vigor readings are greater than $95 \%$ (U.S. Composting Council, 2002). Measurements of all compost samples were identified at $100 \%$. Respirometry tests were conducted to determine the stability (or microbial activity) in the finished compost. The U.S. Composting Council (2002) rates compost with respirometry readings of 0.1-2.0 as "very stable," whereas readings from 2.1 to 8.0 are identified as "stable." The average respirometry reading for the compost samples in this study was 2.2. Individual samples were identified within the range of 2.1-2.3. Subsequently, all compost samples were considered to be stable products for use in the industry.

Although some of the samples did not have the ideal levels of percent moisture and percent solids indicated in compost quality test standards set forth by the U.S. Composting Council (2002), overall, the compost produced was considered a quality product for the horticultural markets (Table 1). Ideally, levels of solids in compost are set at $50 \%$ to $60 \%$, whereas the ideal moisture content is $40 \%$ to $50 \%$ (U.S. Composting Council, 2002). The washed sargassum compost samples were within the ideal ranges with moisture levels at $42.2 \%$ and solids measured $57.8 \%$. Unwashed sargassum compost levels had a greater amount of solids (74.7\%) and less moisture (25.3\%). Compost created using unwashed sargassum contained greater amounts of sand from the beaches, which accounted for more solids. Higher sand content in turn decreased moisture-holding capacity within the compost. However, in some instances, higher amounts of sand in this compost may be seen as beneficial in circumstances where soils need better drainage.

STATISTICAL COMPARISONS. Although all compost created using sargassum met compost quality standards, independent $t$ tests were used to make comparisons between washed and unwashed sargassum compost samples and some significant differences were found (Table 1). The $\mathrm{pH}$ of the compost piles made from washed sargassum was slightly more alkaline when compared with the piles constructed with unwashed sargassum [8.4 vs. 8.1 (Table 1)]. As mentioned previously, $\mathrm{pH}$ was within acceptable levels for both samples and $\mathrm{pH}$ will tend to become more acidic with additional curing time. There was a greater percentage $\mathrm{OM}$ in the unwashed vs. the washed sargassum compost piles [ $23 \%$ vs. $21 \%$ (Table 1)]. This was to be expected as it was noticed that some sargassum material degraded and was lost during the washing process that would lead to less organic material present. There was more potassium in the unwashed vs. the washed sargassum compost piles $(0.45 \%$ vs. $0.41 \%)$, as well as magnesium $(0.28 \%$ vs. $0.24 \%)$ and zinc ( 38 vs. $35.2 \mathrm{mg} \cdot \mathrm{kg}^{-1}$ ) (Table l). However, compost created with washed sargassum had higher levels of copper (10.7 vs. 10.3 $\left.\mathrm{mg} \cdot \mathrm{kg}^{-1}\right)$ and nickel $\left(5.4 \mathrm{vs.} .9 \mathrm{mg} \cdot \mathrm{kg}^{-1}\right)$ (Table 1). Again, the washed compost piles were thought to have slightly more sargassum due to losses in material in the treatment piles during washing. Algae are known to be a good source of macronutrients among other growth stimulating compounds (Verkleij, 1992). Arsenic was more prominent in the unwashed piles but still well within the standards for safety set by the Environmental Protection Agency and for compost quality (Table 1) (Woodbury, 1993).

Respirometry value comparisons showed a significant difference between the washed and unwashed compost samples [2.3 vs. $2.1 \mathrm{mg}$ carbon dioxide per gram of OM per day (Table 1)]. Respirometry, a measure of compost stability, was greater for the washed sargassum compost piles when compared with the unwashed sargassum compost, but lower values demonstrate a more stable sample. However, compost quality test standards indicated the values for both samples were considered stable, cured composts with very limited potential for phytotoxicity and odor.

Trends shown here are considered preliminary given the case-study approach. Results from this study are valuable as very few studies have researched the potential of seaweeds and algae as a bioresource (Eyras et al., 1998; Gangaiah et al., 2017; Khan et al., 2009; Vendrame and Klock-Moore, 2013), and few have looked into composting these materials. This study 
indicated that compost created from sargassum results in a quality product. Although the feedstock was harvested from a saltwater environment, final compost products created did not include salinity levels potentially harmful to plants and can be used to promote plant health. Therefore, when the amount of sargassum that arrives on the shoreline exceeds the amount that can be integrated into dunes, the biomass can be used as a feedstock to create compost valuable to the horticultural industry. The compost may even be considered a "boutique" compost product because of the incorporation of seaweed. Seaweed has been marketed to horticulturists as a liquid fertilizer (Panda and Nayak, 2012; Verkleij, 1992).

Future studies should include a cost-benefit analysis of the removal evaluating the investment and return during harvesting and composting vs. the cost of removal and disposal into a landfill or utilization by integration into dunes which decreases beach space and potentially tourism appeal. Furthermore, as prewashing of the seaweed did not impact the final compost produced in terms of improved quality, future studies may also attempt to identify the maximum amount and proper ratios of sargassum that can be used as a feedstock for compost creation. In addition, studies comparing the nutrient levels between the two methodologies could prove to be useful for different practical applications.

\section{Literature cited}

Abbott, I.A. and E.Y. Dawson. 1978. How to know the seaweeds. 2nd ed. Wm. C. Brown, Dubuque, IA.

Awasthi, D.K. 2005. Cryptogams: Algae, bryophyta and pteridophyta. Krishna Prakashan Media, New Delhi, India.

City of Corpus Christi. 2011. Beach maintenance plan. City of Corpus Christi, Corpus Christi, TX.

Cooperband, L. 2002. The art and science of composting: A resource for farmers and compost producers. 7 July 2017. <http:// www.cias.wisc.edu/wp-content/uploads/ 2008/07/artofcompost.pdf>.

Darlington, W. 2007. Compost - A guide for evaluating and using compost materials as soil amendments. Soil Plant Lab. Form 415. 7 July 2017. <http://www. readbag.com/soilandplantlaboratorypdf-articles-compostaguideforusing $>$.
Dougherty, M. 1999. Field guide to onfarm composting. Natural Resources Coop. Ext. Agr. Eng. Serv. NRAES114.

Eyras, M.C., C.M. Rostagno, and G.E. Defosse. 1998. Biological evaluation of seaweed composting. Compost Sci. Util. 6:74-81.

Fritsch, F.E. 1965. The structure and reproduction of the algae, II. Cambridge Univ. Press, New York, NY.

Gangaiah, C., A. Ahmad, H.V. Nguyen, K.-H. Wang, and T.J.K. Radovich. 2017. Evaluating three invasive algal species as local organic sources of potassium for pak choi (Brassica rapa, Chinensis Group) growth. HortScience 52:436-440.

Gaskill, M. 2015. Sargassum is ruining beaches from Texas to Tobago. 7 July 2017. <http://www.newsweek.com/ $2015 / 07 / 10 /$ sargassum-ruiningbeaches-texas-tobago-347735.html>.

Guiry, D. and G.M. Guiry. 2013. AlgaeBase. 7 July 2017. <http://www. algaebase.org $>$.

Invasive Species Specialist Group. 2011. Global invasive species database. 7 July 2017. <http://www.issg.org/database/ welcome $/>$.

Khan, W., U. Rayirath, S. Subramanian, M. Jithesh, P. Rayorath, D.M. Hodges, A.T. Critchley, J.S. Craigie, J. Norrie, and B. Prithiviraj. 2009. Seaweed extracts as biostimulants of plant growth and development. J. Plant Growth Regul. 28:386399.

Klock-Moore, K. 2000. Comparison of salvia growth in seaweed and biosolids compost. Compost Sci. Util. 8:24-28.

Maze, J., P. Morand, and P. Potoky. 1993. Stabilization of "green tides" ulva by a method of composting with a view to pollution limitation. J. Appl. Phycol. 5:183-190

Meier, E.J., T.M. Waliczek, and M. Abbott. 2014. Composting as a means of managing invasive plants in the Rio Grande River. Invasive Plant Sci. Mgt. 7:473-482.

Montoya, J., T.M. Waliczek, and M. Abbott. 2013. Large-scale composting as a means of managing water hyacinth, Eichhornia crassipes. Invasive Plant Sci. Mgt. 6:243-249.

Panda, D.K.P. and B. Nayak. 2012. Use of sea weed extracts as plant growth regulators for sustainable agriculture. Intl. J. Bio-resource Stress Mgt. 3:404-411.

Pennsylvania State University. 2002. Compost analysis: Sampling and mailing procedure. Pennsylvania State Agr. Anal. Serv. Lab., University Park, PA.

Rogers, K. (ed.). 2011. Fungi, algae and protists. Britannica Educ. Publ., New York, NY.

Round, F.E. 1981. The ecology of algae. Cambridge Univ. Press, New York, NY.

Rynk, R. (ed.). 1992. On-farm composting handbook. INatural Resources Agr. Eng. Serv. (NRAES), Coop. Ext., Ithaca, NY.

Texas General Land Office. 2007. Coastal Texas 2020, executive summary: A clear vision for the Texas coast. 7 July 2017. <http://www.gulfofmexicoalliance.org/ working/restoration/workshops / galveston/tx10_newby.pdf>.

U.S. Composting Council. 2002. Test methods for the examination of composting and composts. Composting Council Res. Educ. Foundation, Holbrook, NY. (CDROM).

Vendrame, W.A. and K. Klock-Moore. 2013. Comparison of herbaceous perennial plant growth in seaweed compost and biosolids compost. Compost Sci. Util. 13:122-126.

Verkleij, F.N. 1992. Seaweed extracts in agriculture and horticulture: A review. Biol. Agr. Hort. 8:309-324.

Walker, P., D. Williams, and T.M. Waliczek. 2006. An analysis of the horticulture industry as a potential valueadded market for compost. Compost Sci. Util. 14:23-31.

Williams, A. and R. Feagin. 2007. Final report: Sargassum and beach erosion: Potential costs and benefits for coastal managers. 7 July 2017. <http://ssl.tamu.edu/ media/1827/06_019_final_report.pdfs.

Williams, A. and R. Feagin. 2010. Sargassum as a natural solution to enhance dune plant growth. Environ. Mgt. 46:738-747.

Williams, A., R. Feagin, and A. Stafford. 2015. Environmental impacts of beach raking of Sargassum spp. on Galveston Island, TX. 7 July 2017. <https://www. researchgate.net/publication / 255572831_Environmental_impacts_of_ beach_raking_of_Sargassum_spp_on_ Galveston_Island_TX>.

Woodbury, P.B. 1993. Potential effects of heavy metals in municipal solid waste composts on plants and the environment. Cornell Waste Mgt. Inst., MSW Composting Fact Sheet \#4. 7 July 2017. <http://compost.css.cornell.edu/ MSWFactSheets/msw.fs4.html>. 